\title{
The Grass Was Greener - Climate Change, One Health, and the High Hopes to Mitigate COVID-19, Avian Influenza, and other Zoonotic Emerging Diseases
}

\author{
D. Katterine Bonilla-Aldana ${ }^{1}$, Álvaro A. Faccini-Martínez², Darío A. Vallejo-Timaran ${ }^{3}$, Flor de María Bocanegra- \\ Viteri $^{4}$, Julian Ruiz-Saenz ${ }^{5}$, Alberto E. Paniz-Mondolfi, ${ }^{6,7}$, Alfonso J. Rodriguez-Morales ${ }^{4,8}$, and Jose Antonio \\ Suárez
}

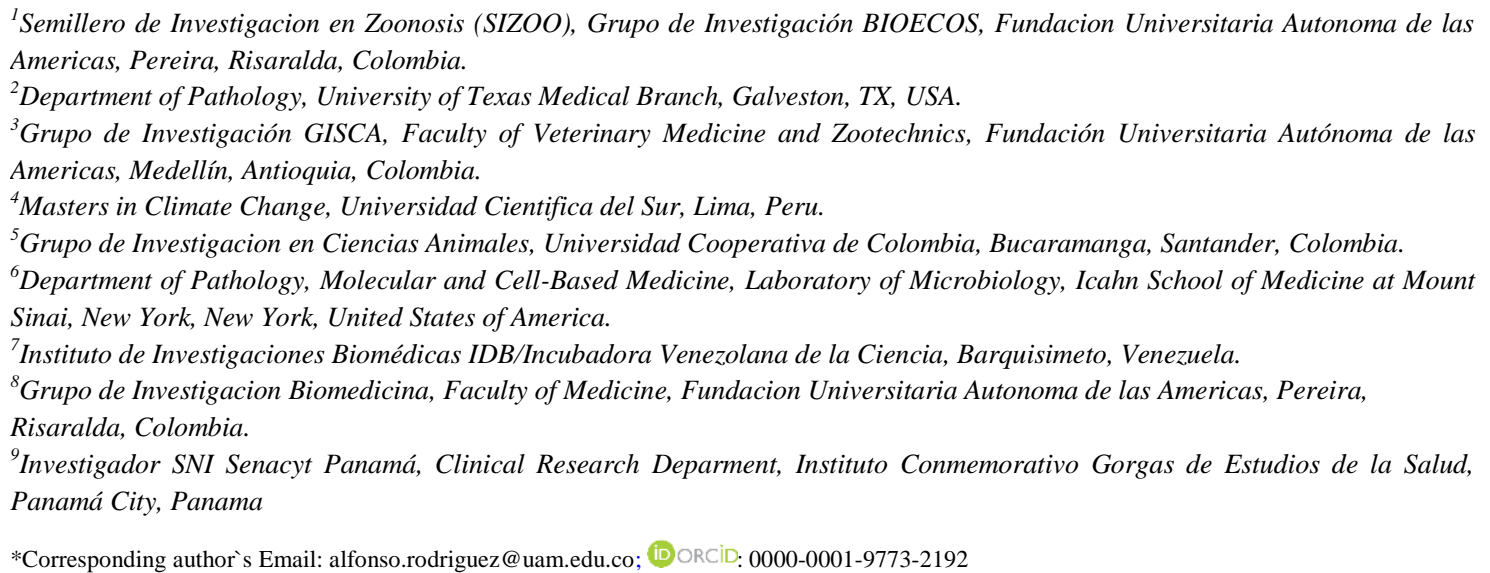

Over the last decades, global warming has significantly affected the world's climate, negatively impacting numerous ecosystems (Cardenas et al., 2006; Beyer et al., 2021; Dupraz and Burnand, 2021). The accumulating influences of climate change, including the rise of the earth's surface temperature and sea level as well as melting glaciers among many other direct and indirect effects (Calel et al., 2020; Harvey et al., 2020), are reshaping, not only the ecological landscape of many world regions, but also setting the stage for emerging diseases sceneries. Floods, droughts, hurricanes (Zambrano et al., 2021), heat waves and surging fires across all continents (Bonilla-Aldana et al., 2019) are all part of the human-driven fingerprint that has led to climate change (Figure 1). These effects have also resulted in a massive reduction of vegetation across many regions around the globe. As the legendary British rock 'n' roll band Pink Floyd once sang in their most celebrated song "High Hopes", “...the grass was greener...” (Pink Floyd, dixit), framed in an environmental context these lyrics should call for a reflection on how climate change is leaving its mark on earth's landscape.

Accelerating climate change is not only affecting human health but also animal health in ways that if left uncontrolled could trigger the emergence/reemergence of climate-sensitive pathogens, vector-borne, and zoonotic diseases (Rodriguez-Morales, 2013; Chowdhury et al., 2018; Chowdhury et al., 2020) (Figure 1). Potential emerging pathogens include most importantly viruses, like the recently evolving Severe Acute Respiratory Syndrome coronavirus 2 (SARS-CoV-2) pandemic for which a number of environmental and climate-related changes appear to have paved its way from animals to human transmission (Yan Yam, 2020).

Possible causes influencing climate-related pathogen emergence include human transgression on wildlife habitats and wildlife exploitation which may lead to increased human-animal, and animal-animals interactions (Figure 1), creating opportunities for pathogens to spill over among species (Yan Yam, 2020). Additionally, the loss of biodiversity compounded by climate change reduces the interface between animals for disease transmission, which increases chances for pathogen exposure and spread to humans, and consequently, potential outbreaks (Escalera-Antezana et al., 2020), epidemics, and even pandemics, as recently seen with the SARS-CoV-2 causing the Coronavirus Disease 2019 (COVID19) (Dhama et al., 2020).

On the other hand, the impact of environmental deleterious human activities, such as deforestation can lead to an increase or shift of selection pressures on different pathogens, particularly viruses (Kalbus et al., 2021; Laporta et al., 2021), Figure 1). Such is the case of SARS-CoV-2, whose origin remains largely unknown (Mohammed, 2021; The Lancet Infectious, 2021) although recent findings have revealed that $96.2 \%$ of its genome shares similarities with bat- 
related coronaviruses; thus, suggesting its probable origin from Chiroptera (Zhou et al., 2020; Bonilla-Aldana et al., 2021). A similar scenario was previously recorded in 1997-1998 with the emergence of the Nipah virus (Uppal, 2000; Chua et al., 2002) following an event of slash-and-burn deforestation that led to a severe haze across much of Southeast Asia and consequent bat (Pteropus) invasions to fruit orchards lying in close proximity to swineherds, which ultimately led to spread amongst pigs followed by cross-species transmission to humans (Breed et al., 2010; Bonilla-Aldana et al., 2019).

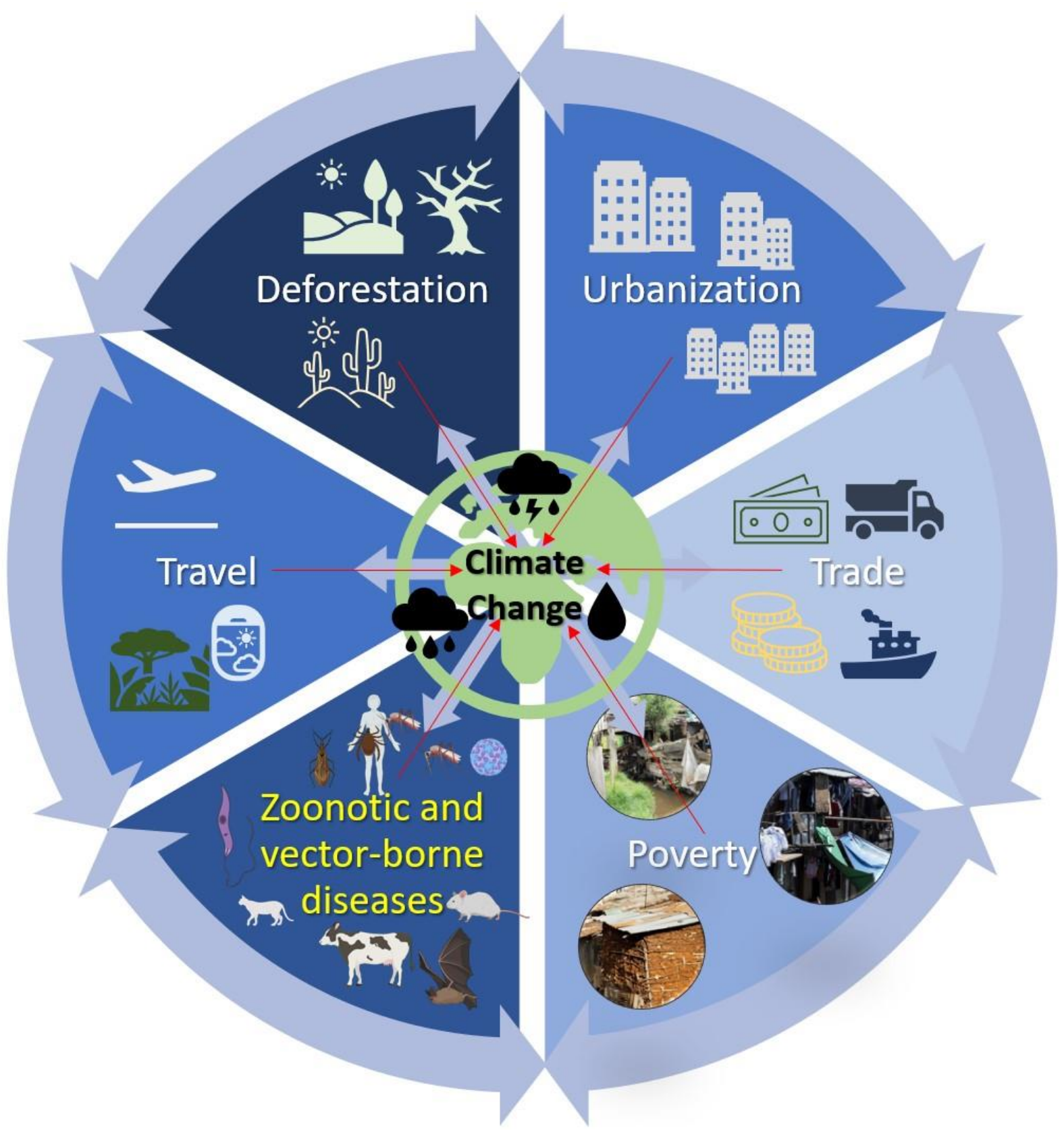

Figure 1. Some selected factors interacting with climate change, and their potential impacts on zoonotic and vectorborne diseases.

In addition, climate change can also influence the incidence and severity of multiple infectious diseases by affecting vector ecology and competency as well as host immune responses. Certain zoonotic respiratory infections may arise in previously spared geographical areas, influenced by a number of climatic causes derived from global warming (Mirsaeidi et al., 2016). An example of this includes avian influenza viruses, which are raising red flags after recent reports on the circulation H5N6, H5N8 (Bonilla-Aldana et al., 2020a), and recently H10N3 (ProMedMail, 2021b). In particular, avian influenza $\mathrm{H} 5 \mathrm{~N} 8$ has been linked to recent outbreaks in poultry farms and amongst wild birds and humans. More recently, the World Health Organization (WHO) alerted about the detection of avian influenza (H5N8) in seven poultry farm workers from Astrakhan Oblast in the Russian Federation (ProMedMail, 2021a; European Food Safety et al., 2021). Likewise, in December 2020, experts from the UK Plant Health Agency (APHA) laboratory isolated 
H5N8 influenza virus during post-mortem analysis performed on common seals (Phoca vitulina), a grey seal (Halichoerus grypus), and a red fox (Vulpes vulpes) from a wildlife rehabilitation center (Zambrano et al., 2021; ProMEDmail, 2021c). Now, in June 2021, a human case due to H10N3 has been reported in China (ProMedMail, 2021b).

Climate change is affecting all areas of society by negatively modulating environmental determinants of both human and animal health, and will continue to do so for generations. The current COVID-19 pandemic is probably associated with the impacts of climate change, due to land use and changes in the interactions between bats and intermediate hosts of coronaviruses. This emphasizes the importance of a One Health approach to tackle the numerous serious ongoing environmental challenges (Bonilla-Aldana et al., 2020b; Bonilla-Aldana et al., 2020c). Given the broad diversity of pathogens affecting wildlife and their continuous evolution, forecasting pathogen emergence through interdisciplinary networking has become the best strategy to reduce the risk of future outbreaks. Efforts to prevent disease emergence should also be emphasized in study areas, such as pathogen surveillance, pathogen-human interaction, and drivers of cross-species transmission. This is the only way we will be able to transit " ... along the long road and on down the causeway" (Pink Floyd, dixit) of the multiple challenges imposed by climate change and its impact on humananimal disease ecology. Looking into the future, we have "high hopes" that humankind will manage to restore its carbon footprint while allowing to mitigate further impacts on climate change and reducing the risk of future pandemics of zoonotic origin.

\section{DECLARATIONS}

\section{Authors' contributions}

DKBA and AJRM conceived the review, developed the first draft of the manuscript. ÁAFM, DAVT, FMBV, JRS, AEPM, and JAS, critically reviewed the manuscript for relevant intellectual content. All authors have read and approved the final version of the paper.

\section{Competing interests}

All authors report no potential conflicts.

\section{REFERENCES}

Beyer RM, Manica A and Mora C (2021). Shifts in global bat diversity suggest a possible role of climate change in the emergence of SARS-CoV-1 and SARS-CoV-2. Science of the Total Environment, 767: Article number 145413. DOI: https://www.doi.org/10.1016/j.scitotenv.2021.145413

Bonilla-Aldana DK, Aguirre-Florez M, Villamizar-Pena R, Gutierrez-Ocampo E, Henao-Martinez JF, Cvetkovic-Vega A, Dhama K, Rabaan A, Sah R, Rodriguez-Morales AJ, et al. (2020a). After SARS-CoV-2, will h5n6 and other influenza viruses follow the pandemic path? Infezioni in Medicina, 28(4): 475-485. Available at: https://pubmed.ncbi.nlm.nih.gov/33257621/

Bonilla-Aldana DK, Dhama K and Rodriguez-Morales AJ (2020b). Revisiting the one health approach in the context of covid-19: A look into the ecology of this emerging disease. Advances in Animal and Veterinary Sciences, 8(3): 234-237. Available at: https://search.bvsalud.org/global-literature-on-novel-coronavirus-2019-ncov/resource/en/covidwho-822918

Bonilla-Aldana DK, Holguin-Rivera Y, Perez-Vargas S, Trejos-Mendoza AE, Balbin-Ramon GJ, Dhama K, Barato P, Lujan-Vega C, and Rodriguez-Morales AJ (2020c). Importance of the one health approach to study the sars-cov-2 in latin america. One Health, 10: Article number 100147. DOI: https://www.doi.org/10.1016/j.onehlt.2020.100147

Bonilla-Aldana DK, Jimenez-Diaz SD, Arango-Duque JS, Aguirre-Florez M, Balbin-Ramon GJ, Paniz-Mondolfi A, Suarez JA, Pachar MR, Perez-Garcia LA, Delgado-Noguera LA et al. (2021). Bats in ecosystems and their wide spectrum of viral infectious potential threats: Sars-Cov-2 and other emerging viruses. International Journal of Infectious Diseases, 102: 87-96. DOI: https://www.doi.org/10.1016/j.ijid.2020.08.050

Bonilla-Aldana DK, Suarez JA, Franco-Paredes C, Vilcarromero S, Mattar S, Gomez-Marin JE, Villamil-Gomez WE, Ruiz-Saenz J, Cardona-Ospina JA, Idarraga-Bedoya SE et al. (2019). Brazil burning! What is the potential impact of the amazon wildfires on vector-borne and zoonotic emerging diseases? - a statement from an international experts meeting. Travel Medicine and Infectious Diseases, 31: Article number 101474. DOI: https://www.doi.org/10.1016/j.tmaid.2019.101474

Breed AC, Yu M, Barr JA, Crameri G, Thalmann CM, and Wang LF (2010). Prevalence of henipavirus and rubulavirus antibodies in pteropid bats, Papua new guinea. Emerging Infectious Diseases, 16(12): 1997-1999. DOI: https://www.doi.org/10.3201/eid1612.100879

Calel R, Chapman SC, Stainforth DA, and Watkins NW (2020). Temperature variability implies greater economic damages from climate change. Nature Communications, 11(1): Article number 5028. DOI: https://www.doi.org/10.1038/s41467-020-18797-8

Cardenas R, Sandoval CM, Rodriguez-Morales AJ, and Franco-Paredes C (2006). Impact of climate variability in the occurrence of leishmaniasis in northeastern Colombia. American Journal of Tropical Medicine Hygiene, 75(2): 273-277. Available at: https://pubmed.ncbi.nlm.nih.gov/16896132/

Chowdhury FR, Ibrahim QSU, Bari MS, Alam MMJ, Dunachie SJ, Rodriguez-Morales AJ, and Patwary MI (2018). The association between temperature, rainfall and humidity with common climate-sensitive infectious diseases in Bangladesh. PLoS ONE, 13(6): e0199579. DOI: https://www.doi.org/10.1371/journal.pone.0199579 
Chowdhury FR, Ibrahim QSU, Bari MS, Alam MMJ, Dunachie SJ, Rodriguez-Morales AJ, and Patwary MI (2020). Correction: The association between temperature, rainfall and humidity with common climate-sensitive infectious diseases in Bangladesh. PLoS ONE, 15(4): e0232285. DOI: https://www.doi.org/10.1371/journal.pone.0232285

Chua KB, Chua BH, and Wang CW (2002). Anthropogenic deforestation, El Nino and the emergence of Nipah virus in Malaysia. Malaysian Journal of Pathology, 24(1): 15-21. Available at: https://pubmed.ncbi.nlm.nih.gov/16329551/

Dhama K, Khan S, Tiwari R, Sircar S, Bhat S, Malik YS, Singh KP, Chaicumpa W, Bonilla-Aldana DK, and Rodriguez-Morales AJ (2020). Coronavirus disease 2019-covid-19. Clinical Microbiology Reviews, 33(4): e00028-20. DOI: https://www.doi.org/10.1128/CMR.00028-20

Dupraz J, and Burnand B (2021). Role of health professionals regarding the impact of climate change on health-an exploratory review. International Journal of Environmental Research and Public Health, 18(6): $3222 . \quad$ DOI: https://www.doi.org/10.3390/ijerph18063222

Escalera-Antezana JP, Rodriguez-Villena OJ, Arancibia-Alba AW, Alvarado-Arnez LE, Bonilla-Aldana DK, and Rodriguez-Morales AJ (2020). Clinical features of fatal cases of Chapare virus hemorrhagic fever originating from rural la Paz, bolivia, 2019: A cluster analysis. Travel Medicine and Infectious Diseases, 36: Article number $101589 . \quad$ DOI: https://www.doi.org/10.1016/j.tmaid.2020.101589

European Food Safety Authority, European Centre for Disease Prevention and Control and European Union Reference Laboratory for Avian Influenza, Adlhoch C, Fusaro A, Gonzales JL, Kuiken T, Marangon S, Niqueux E Staubach C, Terregino C, et al. (2021). Avian influenza overview December 2020 - February 2021. EFSA Journal, 19(3): e06497. DOI: https://www.doi.org/10.2903/j.efsa.2021.6497

Harvey JA, Heinen R, Gols R, and Thakur MP (2020). Climate change-mediated temperature extremes and insects: From outbreaks to breakdowns. Global Changes and Biology, 26(12): 6685-6701. DOI: https://www.doi.org/10.1111/gcb.15377

Kalbus A, de Souza Sampaio V, Boenecke J, and Reintjes R (2021). Exploring the influence of deforestation on dengue fever incidence in the Brazilian Amazonas State. PLoS ONE, 16(1): e0242685. DOI: https://www.doi.org/10.1371/journal.pone.0242685

Laporta GZ, Ilacqua RC, Bergo ES, Chaves LSM, Rodovalho SR, Moresco GG, Figueira EAG, Massad E, de Oliveira TMP, Bickersmith SA et al. (2021). Malaria transmission in landscapes with varying deforestation levels and timelines in the amazon: A longitudinal spatiotemporal study. Scientific Reports, 11(1): Article number 6477. DOI: https://www.doi.org/10.1038/s41598021-85890-3

Mirsaeidi M, Motahari H, Taghizadeh Khamesi M, Sharifi A, Campos M, and Schraufnagel DE (2016). Climate change and respiratory infections. Annals of the American Thoracic Society, 13(8): 1223-1230. DOI: https://www.doi.org/10.1513/AnnalsATS.201511-729PS

Mohammed MEA (2021). The percentages of sars-cov-2 protein similarity and identity with SARS-CoV and batcov ratg13 proteins can be used as indicators of virus origin. Journal of Proteins and Proteomics, pp. 1-11. DOI: https://www.doi.org/10.1007/s42485-021-00060-3

ProMedMail (2021a). Avian influenza, human (02): Russia, h5n8, 1st case. Available at: Https://promedmail.Org/promedpost $/$ ?Id $=8204014$

ProMEDmail (2021b). Promedmail - avian influenza, human (09): China (JS) H10N3, 1st rep. Available at: Https://promedmail.Org/promed-post/?Id=20210602.8416833

ProMEDmail (2021c). Promedmail - avian influenza (45): Europe (UK, Croatia) seal, fox, wild bird, hpai h5n8, oie. Available at: Https://promedmail.Org/promed-post/?Id=20210317.8252821

Rodriguez-Morales AJ (2013). Climate change, climate variability and brucellosis. Recent Patents in Antiinfective Drug Discovery, 8(1): 4-12. DOI: https://www.doi.org/10.2174/1574891x11308010003

The Lancet Infectious D (2021). In an ocean of ashes, islands of order: Who's SARS-CoV-2 origin report. Lancet Infectious Diseases, 21(5): Article number 579. DOI: https://www.doi.org/10.1016/S1473-3099(21)00213-9

Uppal PK (2000). Emergence of Nipah virus in Malaysia. Annans of the New York Academy of Sciences, 916: 354-357. DOI: https://www.doi.org/10.1111/j.1749-6632.2000.tb05312.x

Yan Yam EL (2020). Climate change and the origin of SARS-CoV-2. Journal of Travel Medicine, 27(8): 224. DOI: https://www.doi.org/10.1093/jtm/taaa224

Zambrano LI, Fuentes-Barahona IC, Henriquez-Marquez KI, Vasquez-Bonilla WO, Sierra M, Munoz-Lara F, Luna C, Bonilla-Aldana DK, and Rodriguez-Morales AJ (2021). Covid-19 and hurricanes: The impact of natural disasters during a pandemic in honduras, central america. Prehospital and Disaster Medicine, 36(2): 246-248. DOI: https://www.doi.org/10.1017/S1049023X21000182

Zhou P, Yang XL, Wang XG, Hu B, Zhang L, Zhang W, Si HR, Zhu Y, Li B, Huang CL et al. (2020). A pneumonia outbreak associated with a new coronavirus of probable bat origin. Nature, 579(7798): 270-273. DOI: https://www.doi.org/10.1038/s41586-020-2012-7 